\title{
Gaziantep ìlinde Üretici Düzeyinde Üzüm Pazarlama Yapısı, Üretim ve Pazarlamada Karşılaşılan Sorunlar ve Çözüm Önerileri
}

\author{
Gizem YENER $^{1}$, Arzu SEÇER ${ }^{1^{*}}$ \\ ${ }^{1}$ Çukurova Üniversitesi, Ziraat Fakültesi, Tarım Ekonomisi Bölümü, Sarıçam, Adana. \\ [ORCID: (https://orcid.org/0000-0001-5543-8999 (G. YENER), 0000-0003-1347-4988 (A. SEÇER)] \\ *Sorumlu yazar: asecer@cu.edu.tr
}

Öz

Gaziantep ilinin, Türkiye'nin toplam üzüm üretimi içerisindeki payı \%3.7'dir. Bu ilde bağ alanları 20002016 yılları arasında 317 bin dekardan 162 bin dekara düşmüş olup, üretim ve pazarlamadan kaynaklanan bazı sorunların olduğu bilinmektedir. Bu çalışmada, Gaziantep ilinde üzüm pazarlama yapısı ortaya konulmuş, üretim ve pazarlamadan kaynaklanan sorunlar belirlenmiş ve bu sorunların çözümüne yönelik öneriler sunulmuştur. Araştırma alanında hasat edilen üzümün büyük bölümü sofralık olarak değerlendirilmekte olup pazardaki en büyük alıcısı tüccarlardır. Üreticilerin en önemli üretim sorunları istenilen kalitede ürün elde edilememesi, girdi fiyatlarının yüksek olması ile hastalık ve zararlılarla mücadelede zorluk çekilmesidir. Pazarlamada karşılaşılan en önemli sorunlar ise alıcı sayısının ve çeşidinin azlığı, üreticilerin piyasalarla ilgili bilgi yetersizliği ile işleme tesislerinin nitelik ve sayı bakımından yetersiz olmasıdır. Üreticiler üretim tekniği bakımından bilgilendirilmeli ve kooperatif çatısı altında birleşmeleri için özendirilmelidir. Girişimciler ise işleme tesisleri ve ortak bir ticari marka oluşturulması için bilinçlendirilerek desteklenmelidir.

Anahtar Kelimeler: Bağcılık, Pazarlama yapısı, Üretim sorunları, Pazarlama sorunları, Gaziantep.

\section{Grape Marketing Structure, Production and Marketing Problems and Recommendations at Farmer Level in Gaziantep Province}

\begin{abstract}
Gaziantep province has $3.7 \%$ of total grapes production in Turkey. In this province, vineyard area decreased from 317 thousand decare to 162 thousand decare and it is known that there are some problems in production and marketing. In this study, grapes production marketing structure was revealed, problems in production and marketing were defined and recommendations to solve the problems were presented. In the study area, great part of products (92.3\%) was used as table grapes and traders bought most of the products. The most important problems were lower quality of the product than they wish high input prices and difficulties to manage diseases and pests in the production. Also, in the market farmers had problems about low number and sorts of buyers, insufficient knowledge of producers about markets and low number and insufficient number and quality of processing. Farmers should be informed about production techniques and encouraged to establish cooperatives. Furthermore, entrepreneurs should be conscious and supported about a common trademark.
\end{abstract}

Key Words: Viticulture, Marketing structure, Production problems, Marketing problems, Gaziantep.

\section{Giriş}

Türkiye, dünyada bağcllık için en olup çok eski ve köklü bağcılık kültürü ile elverişli iklim kuşağı üzerinde yer almakta zengin asma gen potansiyeline sahiptir. 
Üzüm, iklim ve toprak koşullarına yüksek adaptasyon, değişik kullanım şekillerine uygunluk, yüksek enerjili besin kaynağı olması ve değişik kullanım alanlarında değerlendirilmesi sebepleriyle önemli bir bitkidir. Üzümde çeşit sayısı diğer meyvelere göre daha fazla olup, dünyada 10,000'nin üzerinde olduğu tahmin edilmektedir. Türkiye ise, asmanın anavatanı olması nedeniyle 200'ün üzerinde üzüm çeşidine sahiptir. Ancak bunlardan sadece 50-60 kadarı ekonomik öneme sahip olduğundan yetiştirmeye değer görülmektedir (Arslan, 2016).

Üzüm sofralık, şaraplık ve kurutmalık olarak değerlendirildiği gibi sirke, pekmez, pestil, reçel, bulama, lokum, meyve suyu, köfter, ezme ve diğer mamul ürünlerin yapımında da kullanılmaktadır. Türkiye'de elde edilen üzümün $\% 51.8^{\prime} i \quad$ sofralık, \%36.6'ü kurutmalık, geriye kalan $\% 11.6$ 'sı ise şaraplık olarak değerlendirilmektedir (TÜiK, 2017). Üretilen şıra ve ürünlerinin miktarına ilişkin veriler istatistiklere yansımamaktadır.

Türkiye'de bağ alanları 2000 yılında 5.4 milyon dekar iken 2016 yılında 4.7 milyon dekara gerilemiştir. Bu dönemde üzüm verimi (çekirdekli sofralık üzüm dikkate alındığında) dekara 404 kg'dan 667 kg'a yükselmiştir. Üretim alanında gerileme olmasına rağmen, verimdeki gelişmeler sonucunda üzüm üretimi 3.6 milyon tondan 4.4 milyon tona yükselmiştir. Türkiye'de 2016 yılında üzüm üretim alanlarının en fazla olduğu iller Manisa (\%18.2), Denizli (\%9.3), Mardin (\%8.0) ve Mersin'dir (\%5.1). Bu çalışmanın yapıldığı Gaziantep ilinin,
Türkiye'nin toplam üzüm üretimi içerisindeki payı ise \%3.7'dir. İldeki bağ alanları 2000 yılında 317 bin dekar iken, 2016 yılında 162 bin dekara gerilemiştir. Üretim ise (verim artışının dekara 380 kg'dan 707 kg'a yükselmesine rağmen) 128 bin tondan 116 bin tona gerilemiştir (Tüik, 2017). Gaziantep ili coğrafi konumu ve üreticilerin bağcılık konusunda deneyimli olmaları nedenleriyle üretim ve ihracat potansiyeli açısından hem bölge, hem de Türkiye ekonomisi açısından büyük önem taşımaktadır. Gaziantep ilinin üzüm üretimi ve ihracatında sahip olduğu öneme rağmen, bu bölgede bağ alanları ve üretim miktarı gerilemektedir.

Aynı zamanda üzüm kolay bozulabilen ve muhafazası oldukça önem taşıyan bir meyvedir. Bu nedenle bu üründe pazarlama açısından eksikliklerin giderilmesi oldukça önemlidir.

Literatürde üzüm üretim ve pazarlaması ile ilgili yapılmış çalışmalar mevcuttur (Huang ve ark., 2008; Gooch ve ark., 2009; Aujla ve ark., 2011; Tasevska, 2012; Kalimang asi ve ark., 2014;). Türkiye'de bağcılık sektörünü teknik yönleriyle ele alan çok sayıda çalışma olmasına rağmen, bu sektörün ekonomik yapısına ağırlık veren çalışmaların sayısının sınırlı düzeyde olduğu söylenebilir (Çoban ve ark., 2001; Tüfekçi ve Tüfekçi, 2006; Çelik ve ark, 2010; Geyikçi, 2013; Gözener ve ark., 2014; Cebeci ve Akın, 2014; Çakır ve ark, 2015; Kiracı ve Özer, 2015; Semerci ve ark, 2015). Öyle ki, literatürde, Gaziantep ilinde üzüm pazarlama yapısı üzerine yapılmış bir çalışmaya rastlanmamıştır. 
Yapılan bu çalışma ile Gaziantep ilinde üzüm işletmelerinin genel özellikleri ve üretici düzeyinde pazarlama yapısı ortaya konulmuş, üreticilerin üzüm üretiminde ve pazarlamasında karşılaştıkları sorunlar belirlenerek bu sorunların giderilmesine yönelik öneriler sunulmuştur.

\section{Materyal ve Metot}

\section{Materyal}

Çalışmanın ana materyalini üzüm yetiştiren üreticiler ile yüz yüze görüşmeler sonucu elde edilen birincil veriler oluşturmaktadır. Anket formları, benzer konularda yapılmış çalışmalardan faydalanılarak ve uzman kişilerin görüşleri alınarak hazırlanmıştır. Ankette yer alan soruların uygunluğu ve yeterliliğini test edebilmek amacıyla pilot anket çalışması yapılmış, gerekli düzeltmeler sonucunda ankete son şekli verilmiştir. Alan çalışması, 1-15 Şubat 2016 tarihleri arasında yapılmış ve 2015 üretim dönemine ait veriler toplanmıştır. Anket formu, 3 temel bölümden oluşmaktadır. Birinci bölümde, üreticilerin ve işletmelerin genel özelliklerini; ikinci bölümde işletmelerde üzüm pazarlama yapısını; üçüncü bölümde ise üreticilerin üretim ve pazarlama sorunları ile geleceğe yönelik beklentilerini belirlemeye yönelik sorular sorulmuştur.

\section{Metot}

Araştırma alanı olarak, Türkiye üzüm üretiminin \%3.7'ini karşılayan Gaziantep ili seçilmiştir. Örnek kapsamına alınacak ilçeler, il üretimine katkılarının yanı sıra
Gıda Tarım ve Hayvancılık Bakanlığı (GTHB) il ve ilçe Müdürlükleri yetkililerinin görüşleri dikkate alınarak, pazarlama açısından Gaziantep ilini temsil edecek şekilde gayeli örnekleme yöntemi ile belirlenmiştir. Bu yöntemle, üzüm üretiminin \%49.6'sını sağlayan Islahiye ve Şehitkamil ilçeleri örneğe dâhil edilmiştir (TUiK, 2017). Bu ilçelerde, GTHB İlçe Müdürlüğü yetkililerinden alınan bilgiler doğrultusunda, üzüm üretiminin yaygın olduğu köyler de gayeli örnekleme yöntemi ile seçilmiştir. Bu şekilde Islahiye'nin Altınüzüm, Sulumağara, Yeşilyurt ve Boğaziçi; Şehitkâmil'in Bedirkent, Suboğazı, Işıklı ve Özümsöğüt köyleri çalışma kapsamına alınmıştır. Bu köylerde bağcılıkla uğraşan 565 kişi araştırmanın çerçeve kitlesini oluşturmaktadır. Bu çerçeve listeye "Basit Tesadüfi Örnekleme Yöntemi" uygulanarak anket yapılacak üretici sayısı belirlenmiştir. Örnek hacmi \%90 güven aralığında, ortalamadan \%10 sapma ile 63 olarak belirlenmiştir. Alan çalışması sırasında bu rakam 65 üreticiye tamamlanmıştır. Elde edilen veriler frekans, oran ve ortalamalar hesaplanarak sunulmuştur.

\section{Araştırma Bulguları}

İsletmecilerin ve İşletmelerin Genel özellikleri

Üreticilerin \%30.8'i 41-50 yaş aralığında olup yaş ortalaması 50.4 olarak belirlenmiştir. Bu kişilerin \%80.0'i ilkokul, $\% 10.8^{\prime} i$ ise lise mezunudur (Çizelge 1 ). Üreticilerin aile genişliği ortalama 6.0 kişi ve bağcılık süresi ortalama 40.4 yıldır. 
Üreticilerin \%29.2'si tarım dışı faaliyette bulunmaktadır (market, kahvehane sahibi, hırdavatçı, yem-kömür dükkanı, emekli, ziraat mühendisi, kasap, emlakçı).

Çizelge 1. İşletmecilerin yaş grupları ve eğitim düzeyleri

Table 1. Farmers' age groups and education level

\begin{tabular}{|c|c|c|c|c|c|}
\hline $\begin{array}{l}\text { Yaş grupları } \\
\text { Age groups }\end{array}$ & $\begin{array}{l}\text { Adet } \\
\text { Number }\end{array}$ & $\begin{array}{c}\text { Oran (\%) } \\
\text { Percentage (\%) }\end{array}$ & $\begin{array}{l}\text { Eğitim düzeyi } \\
\text { Education level }\end{array}$ & $\begin{array}{c}\text { Adet } \\
\text { Number }\end{array}$ & $\begin{array}{c}\text { Oran (\%) } \\
\text { Percentage (\%) }\end{array}$ \\
\hline $30-40$ & 13 & 20.0 & $\begin{array}{l}\text { ilkokul } \\
\text { Primary }\end{array}$ & 52 & 80.0 \\
\hline $41-50$ & 20 & 30.8 & $\begin{array}{l}\text { Ortaokul } \\
\text { Secondary }\end{array}$ & 1 & 1.5 \\
\hline $51-60$ & 17 & 26.2 & $\begin{array}{l}\text { Lise } \\
\text { High school }\end{array}$ & 7 & 10.8 \\
\hline 61- & 15 & 23.1 & $\begin{array}{l}\text { Üniversite } \\
\text { University }\end{array}$ & 5 & 7.7 \\
\hline $\begin{array}{l}\text { Toplam } \\
\text { Total }\end{array}$ & 65 & 100.0 & $\begin{array}{l}\text { Toplam } \\
\text { Total }\end{array}$ & 65 & 100.0 \\
\hline
\end{tabular}

İşletmelerde ortalama bağ arazisi 24.5 dekar olup yetiştirilen diğer ürünlerden en önemlileri ise Antep fıstığı (3.9 dekar), buğday (3.4 dekar) ve elmadır (1.4 dekar). İşletmelerde düşük oranda da arpa, kiraz, acur ve diğer sebze türleri de yetiştirilmektedir. Bazı işletmelerin bitkisel üretimle beraber hayvancilık da yapmaktadır. İşletmelerde 2.4 adet büyükbaş ve 6.0 adet küçükbaş hayvan bulunmaktadır.

\section{Pazarlama Yapısı}

Ele alınan işletmelerde, işletme başına ortalama 16.1 ton üzüm elde edilmekte, bu ürünün \%92.3'ü sofralık olarak satılmakta, \%7.1'i şıra olarak işlenmekte ve geriye kalan \%0.6'sı kurutma amacıyla ayrılmaktadır (Çizelge 2). İşletmelerde üretilen üzümün oldukça düşük bir miktarı aile tüketimi için ayrılmakta veya işçilere hediye olarak verilmektedir. Bu nedenle üretilen ürünün tamamına yakınının pazara sunulduğu söylenebilir.

İşletmelerde şıra randımanı $(100 \mathrm{~kg}$ üzümden elde edilen şıra miktarı) $\% 15.5$ olup, ortalama $175.7 \mathrm{~kg}$ şıra elde edilmektedir. Elde edilen şıra, pekmez olarak değerlendirildiği gibi yerel olarak pestil, tatlı sucuk (bandırma) olarak isimlendirilen ürünlere de işlenmektedir. $\mathrm{Bu}$ işletmelerde elde edilen şıra ve ürünlerinin pazarlama oranı $\% 94.6^{\prime}$ dır. Kuru üzüm randımanı (100 kg üzümden elde edilen üzüm miktarı) ise \%28.7 olup, elde edilen kuru üzüm miktarı ortalama $28.5 \mathrm{~kg}$ dır.

Türkiye'de elde edilen üzümün $\% 51.8$ 'i sofralık, \%36.6'sı kurutmalık, geriye kalan $\% 11.6$ 'sı ise şaraplık olarak değerlendirilmektedir (TÜiK, 2017). Araştırma alanındaki işletmeler ürün değerlendirme şekli bakımından Türkiye genelinden farklı özellik göstermektedir. 
Çizelge 2. İşletmelerde üzümün değerlendirilme şekli

Table 2. Evaluation types of grapes in the farms

\begin{tabular}{|l|c|c|}
\hline $\begin{array}{l}\text { Ürün değerlendirme şekli } \\
\text { Product evaluation types }\end{array}$ & $\begin{array}{c}\text { Miktar (kg) } \\
\text { Quantity (kg) }\end{array}$ & $\begin{array}{c}\text { Oran (\%) } \\
\text { Percentage (\%) }\end{array}$ \\
\hline $\begin{array}{l}\text { Sofralık üzüm } \\
\text { Table grape }\end{array}$ & $1,4836.2$ & 92.3 \\
\hline $\begin{array}{l}\text { Şıraya işlenen } \\
\text { Processed in wish (wort) }\end{array}$ & $1,133.8$ & 7.1 \\
\hline $\begin{array}{l}\text { Kurutmalık } \\
\text { Drying }\end{array}$ & 99.2 & 0.6 \\
\hline $\begin{array}{l}\text { Toplam } \\
\text { Total }\end{array}$ & $16,069.2$ & 100.0 \\
\hline
\end{tabular}

Ürünlerin pazarlaması üretim içindeki payı $\% 60.4$ olup, geriye kalan bölgesindeki komisyoncu, tüccar veya üreticiler ise (\%39.6) mevcut üretim yerel tüccarlar tarafından yapılmaktadır. döneminde kendilerine gelen aracılar Üreticiler, sofralık üzümün tamamına içerisinde en yüksek fiyatı verenlere yakınını (\%95.8) tüccarlara satmaktadır. satışlarını yapmaktadırlar.

Geriye kalan ürün (\%3.5) ise doğrudan Pazara sunulan şıranın \%86.1'i tüketiciler tarafından satın alınmaktadır. tüccarlara, geriye kalan \%13.9'u ise Üreticilerin bir kısmının hasattan önce doğrudan tüketicilere satılmaktadır. Elde yerel tüccarlarla anlaştıkları, güven edilen kuru üzüm ise sırasıyla tüccarlara duydukları ve daha önceki yıllarda da (\%59.4), doğrudan tüketicilere (\%29.8) ve satış yaptıkları aracıları tercih etmektedir. işleme tesislerine (\%10.8) satılmaktadır Hasat öncesi anlaşmayla üzüm satışı (Çizelge 3). yapan üreticilerin toplam üreticiler

Çizelge 3. Kullanım şekillerine göre üzümde pazarlama yerleri Table 3. Marketing place in grapes according to usage shapes

\begin{tabular}{|l|r|r|r|r|r|r|}
\hline \multirow{2}{*}{$\begin{array}{l}\text { Alıcılar } \\
\text { Buyers }\end{array}$} & \multicolumn{2}{|c|}{$\begin{array}{c}\text { Sofralık üzüm } \\
\text { Table Grape }\end{array}$} & \multicolumn{2}{c|}{$\begin{array}{c}\text { Şra ürünleri } \\
\text { Wish products }\end{array}$} & \multicolumn{2}{c|}{$\begin{array}{c}\text { Kuru üzüm } \\
\text { Raisins }\end{array}$} \\
\cline { 2 - 7 } & $\begin{array}{c}\text { Miktar (kg) } \\
\text { Quantity (kg) }\end{array}$ & $\begin{array}{c}\text { Oran (\%) } \\
\text { Percent.(\%) }\end{array}$ & $\begin{array}{c}\text { Miktar (kg) } \\
\text { Quantity (kg) }\end{array}$ & $\begin{array}{c}\text { Oran (\%) } \\
\text { Percent. (\%) }\end{array}$ & $\begin{array}{c}\text { Miktar (kg) } \\
\text { Quantity (kg) }\end{array}$ & $\begin{array}{c}\text { Oran (\%) } \\
\text { Percent.(\%) }\end{array}$ \\
\hline $\begin{array}{l}\text { Tüccar } \\
\text { Dealer }\end{array}$ & $13,633.1$ & 95.8 & 143.1 & 86.1 & 16.9 & 59.4 \\
\hline $\begin{array}{l}\text { Tüketici } \\
\text { Consumer }\end{array}$ & 604.6 & 4.2 & 23.1 & 13.9 & 8.5 & 29.8 \\
\hline $\begin{array}{l}\text { İşleme Tesisi } \\
\text { Processor }\end{array}$ & - & - & - & & 3.1 & 10.8 \\
\hline $\begin{array}{l}\text { Toplam } \\
\text { Total }\end{array}$ & $14,237.7$ & 100.0 & 166.2 & 100.0 & 28.5 & 100.0 \\
\hline
\end{tabular}


Üreticiler üzümü ${ }^{1}$, hasat ettikten sonra satış yerine teslime kadar bir takım pazarlama hizmetlerini de (paketleme, dereceleme, depolama ve taşıma) yerine getirmektedir.

Bağcılık işletmelerinde genel olarak hasat, sofralık üzümler olgunluğa ulaştıkça birkaç defada (genellikle bir hafta aralıklarla) yapılmaktadır. Üreticilerin \%32.3'ü sınıflandırma yaparken \%67.7'si sınıflandırma yapmaya gerek duymamaktadır. Sınıflandırma yapılırken üzüm; ekstra, birinci sınıf ve ikinci sınıf olmak üzere 3 kalite sınıfına ayrılmaktadır.

Hasat edilen üzümlerin pazara bozulmadan taşınması için tahta ya da oluklu mukavvadan yapılmış taşıma kapları kullanılmalı ve tahta kasa kullanılacaksa tabanı ve kenarları kâğıtla kaplanmalıdır (Çalkan ve Güler, 2007). Ele alınan işletmelerin tamamında tahta kasa kullanılmakta, ürünün bozulmasını engellemek amacıyla kasalar kâğıtla kaplanmaktadır. Üreticilerin tamamı paketlemeyi üretim alanında yapmaktadır. Paketleme işlemi, işletmelerin \%49.2'sinde sadece üretici ve ailesi tarafından, $\% 50.8^{\prime}$ inde ise ek olarak yabancı işçi çalıştırılarak yapılmaktadır.

Üzüm hasadının çok kısa bir süre içerisinde olmasına karşın satışların kısa sürede yapılamaması, iç piyasada uzak mesafelere ya da ihracata yönelik nakliyatta sorunlar oluşması sebebiyle üzümün soğuk şartlarda muhafaza edilerek mümkün olduğunca tazeliğinin

\footnotetext{
1 Sadece sofralık üzüme uygulanan pazarlama hizmetleri açıklanmıştır.
}

korunması gerekmektedir (Çalkan ve Güler, 2007). Üzüm kasaları kamyonlara yüklenmeden önce kamyon kasasının iç kısmının temizliği, kasalar sallanmayacak şekilde istif edilmesi ve kasa sıcaklığının belli bir seviyede tutulması gerekmektedir (Karakaş, 2015). Toptancı ve tüccarlar, sofralık üzümü üreticilerin işletmesinden frigofirik kamyonlarla almaktadır. Yörede bu şekilde satın alınan ürün toplam ürünün \%95.8'ini oluşturmakta ve genellikle üretim bölgesi dışına satıldığı bilinmektedir. Bu durumda, sofralık üzüm uygun şekilde muhafaza edilerek taşıma işlemi gerçekleştirilmektedir. Geriye kalan ürün ise üreticiler tarafından kamyonet gibi araçlarla pazara taşınarak işletme dışında satışı gerçekleştirilmektedir.

Sofralık üzümün hasattan sonra uygun koşullarda bekletilmesi ya da depolanması ürünün muhafaza süresini uzatmaktadır. Uygun depo koşullarının oluşmasında ise ortam sıcaklığı ve nemi, hava hareketi, istifleme şekli ve atmosfer koşulları etkilidir (Eriş ve Türkben, 1984). TS 101 Sofralık Üzüm Standardında Sofralık üzümlerin depolanmasında ortam sıcaklığının -1 ile $0{ }^{\circ} \mathrm{C}$, bağıl nemin de \% 90-95 arasında olması gerektiği belirtilmektedir. Araştırma alanında soğuk hava deposu sadece 1 adet olup şahsa aittir. Araştırma alanında üreticiler bu depodan çabuk bozulabilir bir ürün olduğundan dolayı üzüm depolamak için yararlanmayı tercih etmemektedir. Üretim bölgesi dışına sunulan ürünün, soğuk muhafazasına ilişkin herhangi bir sorunla karşılaşılmadığı ifade edilmektedir. Ancak üretim bölgesi içinde 
pazarlanan ürünün, standartlara uygun olmayan şekilde muhafaza edildiği ve bu aşamada kalite kayıplarının ortaya çıktığı söylenebilir.

Araştırma alanında, elde edilen ürünlerin ortalama satış fiyatları sofralık üzümde $1.2 \mathrm{TL}$ (0.50 kuruşa kadar düşmektedir); pekmezde $18.2 \mathrm{TL}$; pestilde 15.5 TL ve kuru üzümde 7.6 TL'dir. Üreticilerin $\% 90.8^{\prime} i$ satış sonrasında ürün bedellerini peşin olarak almaktadır. Bir üretim döneminde üreticilere ortalama 2 adet alıcı gelmektedir.

Fiyatın belirlenmesinde 65 üreticiden $\% 16.9$ 'u alıcının teklifini kabul ettiğini, \%32.3'ü pazar fiyatını öğrendikten sonra en yüksek fiyatı veren alıcıya ürününü sattığını, \%38.5'i pazarlık yaparak fiyatı belirlediğini, geriye kalan \%12.3'ü ise ürününü güven duyduğu alıcıya sattığını ifade etmiştir. Üretici fiyatı belirleme aşamasında ürün fiyatını tüccardan (\%55.3), düzenli olarak pazara giderek (\%33.8) ve yakın çevrelerinden bilgi alarak (\%10.9) öğrendiklerini belirtmişlerdir.

\section{Bölgedeki Üretimin Yapısı}

Üreticilerin bağcılık yapmasının başlıca sebepleri üretim bölgesinde iklim ve toprak uygunluğundan dolayı tercih edilen bir ürün olması (\%93.8), getirisinin yüksek olması (\%33.8), üzüm yetiştiriciliğinin kolay olması (\%29.2) ve pazarlamasının kolay olmasıdır (\%6.2; Üreticiler birden fazla seçenek belirtmiştir).

Son beş yıl içerisinde üreticilerin \%75.4'ünün dikim alanı değişmemiştir. \%16.9'unun dikim alanı azalmış, \%7.7'sinin dikim alanı artmıştır. Üreticilerin dikim alanlarını azaltmasının başlıca sebepleri göre maliyet artışından dolayı önceki yıllara daha az kar elde etmeleri, bakımının zor olması, girdi gereksiniminin yüksek olması ve yörede üzüm verimde azalma meydana gelmesidir.

Üreticilerin \%67.7'si gelecekte üzüm dikim alanlarını değiştirmek istemezken, \%24.6'sı artırabileceklerini, \%7.7'si azaltmak istediklerini ifade etmişlerdir.

\section{Üreticilerin Örgütlenme Yapısı}

Üreticilerin \%16.9'u (11 kişi) Tarım Kredi Kooperatifi'ne, Kiraz Üreticileri Birliği'ne ve Tarımsal Kalkınma Kooperatifi'ne üyedir.

Araştırma alanında, üreticilerin \%89.2'si üzüm ve ürünlerinin pazarlaması konusunda faaliyet gösterecek üretici birlikleri veya kooperatiflerin faydalı olacağını düşünmektedir. Bu konuyla ilgili olarak üreticilerin ihtiyacının düzeyini belirlemek amacıyla, üreticilere 3'lü likert ölçeğiyle pazarlama kooperatiflerinin sağlayacağı faydalar sorulmuş ve her bir unsurun kendileri için önem düzeyini ifade etmeleri istenmiştir. Üreticiler açısından pazarlama kooperatiflerinin sağlayacağı en büyük fayda pazarlama alternatifi yaratması (ort:3.0), ödemelerin zamanında yapılması (ort:2.9) ve markalaşmada öncülük ve kolaylık sağlamasıdır (ort:2.9). Üreticilerin pazarlama kooperatifinden diğer beklentileri ise alıcı bulmada kolaylık sağlamasıdır (Çizelge 4) 
Çizelge 4. Üreticilerin pazarlama kooperatiflerinden beklentileri

Table 4. Farmer's expectation towards marketing cooperatives

\begin{tabular}{|c|c|c|c|c|c|c|c|}
\hline \multicolumn{2}{|l|}{$\begin{array}{l}\text { Üreticilerin beklentileri } \\
\text { Expectations of the producers }\end{array}$} & $\begin{array}{l}\text { Önemli } \\
\text { Değil } \\
\text { Not } \\
\text { important }\end{array}$ & $\begin{array}{l}\text { Orta derecede } \\
\text { önemli } \\
\text { Somewhat } \\
\text { important }\end{array}$ & $\begin{array}{c}\text { Önemli } \\
\text { Important }\end{array}$ & $\begin{array}{l}\text { Toplam } \\
\text { Total }\end{array}$ & $\begin{array}{l}\text { Ort } \\
\text { Ave. }\end{array}$ & $\begin{array}{l}\text { SS } \\
S D\end{array}$ \\
\hline \multirow{2}{*}{$\begin{array}{l}\text { Pazarlama alternafinin olması } \\
\text { Being a marketing alternative }\end{array}$} & $\mathrm{n}$ & 0.0 & 0.0 & 65 & 65 & \multirow{2}{*}{3.0} & \multirow{2}{*}{0.0} \\
\hline & $\%$ & 0.0 & 0.0 & 100.0 & 100.0 & & \\
\hline \multirow{2}{*}{$\begin{array}{l}\text { Ödemenin zamanında yapılması } \\
\text { Timely payment }\end{array}$} & $\mathrm{n}$ & 3 & 3 & 59 & 65 & \multirow{2}{*}{2.9} & \multirow{2}{*}{0.5} \\
\hline & $\%$ & 4.6 & 4.6 & 90.8 & 100.0 & & \\
\hline \multirow{2}{*}{$\begin{array}{l}\text { Markalaşmada öncülük ve kolaylık } \\
\text { Pioneering and convenience in branding }\end{array}$} & $\mathrm{n}$ & 0.0 & 8 & 57 & 65 & \multirow{2}{*}{2.9} & \multirow{2}{*}{0.3} \\
\hline & $\%$ & 0.0 & 12.3 & 87.7 & 100.0 & & \\
\hline \multirow{2}{*}{$\begin{array}{l}\text { Daha iyi fiyat olanağı } \\
\text { Better price facility }\end{array}$} & $\mathrm{n}$ & 1 & 8 & 56 & 65 & \multirow{2}{*}{2.8} & \multirow{2}{*}{0.4} \\
\hline & $\%$ & 1.5 & 12.3 & 86.2 & 100.0 & & \\
\hline \multirow{2}{*}{$\begin{array}{l}\text { Alıcı bulmada kolaylık } \\
\text { Convenience in finding buyers }\end{array}$} & $\mathrm{n}$ & 0.0 & 20 & 45 & 65 & \multirow{2}{*}{2.7} & \multirow{2}{*}{0.5} \\
\hline & $\%$ & 0.0 & 30.8 & 69.2 & 100.0 & & \\
\hline \multirow{2}{*}{$\begin{array}{l}\text { Pazar bilgilerini edinmede kolaylık } \\
\text { Convenience in getting market } \\
\text { information }\end{array}$} & $\mathrm{n}$ & 0.0 & 35 & 30 & 65 & \multirow[b]{2}{*}{2.5} & \multirow[b]{2}{*}{0.5} \\
\hline & $\%$ & 0.0 & 53.8 & 46.2 & 100.0 & & \\
\hline \multirow{2}{*}{$\begin{array}{l}\text { Girdi temininde kolaylık } \\
\text { Convenience in providing inputs }\end{array}$} & $\mathrm{n}$ & 2 & 47 & 16 & 65 & \multirow{2}{*}{2.2} & \multirow{2}{*}{0.5} \\
\hline & $\%$ & 3.1 & 72.3 & 24.6 & 100.0 & & \\
\hline \multirow{2}{*}{$\begin{array}{l}\text { Kredi olanağı sağlaması } \\
\text { Providing credit facility }\end{array}$} & $\mathrm{n}$ & 14 & 22 & 29 & 65 & \multirow{2}{*}{2.2} & \multirow{2}{*}{0.8} \\
\hline & $\%$ & 21.5 & 33.8 & 44.6 & 100.0 & & \\
\hline İşleme olanağı sağlaması & $\mathrm{n}$ & 24 & 13 & 28 & 65 & \multirow{2}{*}{2.1} & \multirow{2}{*}{0.9} \\
\hline Providing processing facility & $\%$ & 36.9 & 20.0 & 43.1 & 100.0 & & \\
\hline \multirow{2}{*}{$\begin{array}{l}\text { Satış sırasında etik olmayan } \\
\text { davranışların azalması } \\
\text { Decreasing in unethical behaviors }\end{array}$} & $\mathrm{n}$ & 18 & 34 & 13 & 65 & \multirow[b]{2}{*}{1.9} & \multirow[b]{2}{*}{0.7} \\
\hline & $\%$ & 27.7 & 52.3 & 20.0 & 100.0 & & \\
\hline \multirow{2}{*}{$\begin{array}{l}\text { Dereceleme ve standardizasyonun } \\
\text { iyileşmesi } \\
\text { Better grading and standardization }\end{array}$} & $\mathrm{n}$ & 44 & 20 & 1 & 65 & \multirow[b]{2}{*}{1.3} & \\
\hline & $\%$ & 67.7 & 30.8 & 1.5 & 100.0 & & 0.5 \\
\hline Taşıma olanaklarının iyileşmesi & $\mathrm{n}$ & 55 & 6 & 4 & 65 & 1 & 05 \\
\hline Better transportation facility & $\%$ & 84.6 & 9.2 & 6.2 & 100.0 & 1.2 & 0.5 \\
\hline Paketleme olanaklarının iyileşmesi & $\mathrm{n}$ & 58 & 4 & 3 & 65 & 1.2 & 05 \\
\hline Better packaging facility & $\%$ & 89.2 & 6.2 & 4.6 & 100.0 & & \\
\hline
\end{tabular}

Üreticilerin Üzüm Üretim ve Pazarlama Sorunları

Üreticilerin üzüm üretiminde karşılaştıkları en önemli sorun ürün kalitesinin istedikleri düzeyde olmamasıdır. Bunun yanı sıra girdi fiyatlarının yüksekliği, hastalık ve zararlılarla mücadelede bilgi yetersizliği ve işgücü ücretlerinin yüksekliği karşılaşılan önemli sorunlardır (Çizelge 5).
Girdi fiyatlarının yüksekliği, ürün fiyatlarının istenilen düzeyin altında olduğu da düşünüldüğünde üreticilerin elde ettiği karın azalmasına sebep olan önemli bir faktördür. Bununla beraber üzüm hasadı işgücüne dayanmakta ve yoğun işgücü masrafı gerektirmektedir. Bu durum da üzüm üretiminden elde edilen karın düşmesine sebep olmaktadır. 
Çizelge 5. Üreticilerin üzüm üretimindeki sorunları

Table 5. Farmers problems in grapes production

\begin{tabular}{|l|c|c|}
\hline $\begin{array}{l}\text { Sorunlar } \\
\text { Problems }\end{array}$ & $\mathrm{n}$ & $\begin{array}{c}\text { Oran (n/65) } \\
\text { Percentage (n/65) }\end{array}$ \\
\hline $\begin{array}{l}\text { İstenilen kalitede ürün elde edilmemesi } \\
\text { Low product quality }\end{array}$ & 60 & 92.3 \\
\hline $\begin{array}{l}\text { Girdi fiyatlarının yüksekliği } \\
\text { High input prices }\end{array}$ & 58 & 89.2 \\
\hline $\begin{array}{l}\text { Hastalık ve zararlılarla mücadelede bilgi yetersizliği } \\
\text { Inadequate information on disease and harmful struggle }\end{array}$ & 46 & 70.8 \\
\hline $\begin{array}{l}\text { İsügü ücretlerin yüksekliği } \\
\text { High labor cost }\end{array}$ & 23 & 35.4 \\
\hline $\begin{array}{l}\text { Diğer* } \\
\text { Others }\end{array}$ & 11 & 16.9 \\
\hline
\end{tabular}

*: Sulama, gübreleme ve hasat.

Üreticilerin üzüm pazarlamasında karşılaştıkları sorunları belirlemek amacıyla araştırma alanıyla ilgili önceden edilen bilgiler doğrultusunda üreticilere karşıllaşabilecekleri sorunlar sorulmuş ve 3’lü likert ölçeği ile bu sorunların kendileri için önem düzeyini belirlemeleri istenmiştir. Görüşülen üreticiler pazarlamada karşılaştıkları en önemli sorunlar; alıcı sayısının ve çeşidinin azlığı (ort: 3.0), üreticilerin piyasalar hakkında bilgi yetersizliği, işleme tesislerinin nitelik olarak yetersiz olması (ort: 2.2 ) ve işleme tesislerinin sayılarının azlığıdır (ort: 2.1) (Çizelge 6). Alıcı sayısının ve çeşidinin az olması üreticilerin alıcılar karşısında rekabet gücünün zayıflatmakta ve fiyat konusunda üreticilerin dezavantajlı duruma gelmesine sebep olmaktadır. Bölgede üzümü işleyen işletmelerin varlığı ise piyasaya sunulan üründe katma değer artışına sebep olacak ve üretici gelirlerinde artış sağlayacaktır.

Üreticilerin sorunlarının ve beklentilerinin belirlenmesi ile ilgili sofralık üzüm ve mamullerinde markalaşma konusunda düşünceleri ve yaşadıkları sorunlar da sorulmuştur. Üreticilerin \%90.8'si Gaziantep ilinde elde edilen sofralık üzümün marka olabileceğini ifade ederken, bu oran üzümden elde edilen ürünler için \%32.3'dür. Markalaşmada yaşanan en önemli sorunlar ise örgütlenmeden kaynaklanan eksiklikler (\%43.1), bilgi eksikliği (\%35.4), maddi olanaksızlıklar (\%13.8), küçük ölçeklilik (\%4.6) ve hedef pazarlara ulaşmada yaşanan zorluklardır (\%3.1). 
Çizelge 6. Üreticilerin üzüm pazarlamasında karşılaştıkları sorunlar

Table 6. Farmer's problems in grapes marketing

\begin{tabular}{|c|c|c|c|c|c|c|c|}
\hline \multicolumn{2}{|l|}{$\begin{array}{l}\text { Pazarlama sorunları } \\
\text { Marketing problems }\end{array}$} & $\begin{array}{l}\text { Önemli } \\
\text { değil } \\
\text { Not } \\
\text { important }\end{array}$ & $\begin{array}{l}\text { Orta derecede } \\
\text { önemli } \\
\text { Somewhat } \\
\text { important }\end{array}$ & $\begin{array}{l}\text { Önemli } \\
\text { Important }\end{array}$ & $\begin{array}{l}\text { Toplam } \\
\text { Total }\end{array}$ & $\begin{array}{l}\text { Ort } \\
\text { Ave. }\end{array}$ & $\begin{array}{l}\text { SS } \\
\text { SD }\end{array}$ \\
\hline \multirow{2}{*}{$\begin{array}{l}\text { Alıcı sayısının ve çeşidinin azlığı } \\
\text { the low number and insufficient types } \\
\text { of buyers }\end{array}$} & $\mathrm{n}$ & 0 & 3 & 62 & 0 & \multirow[b]{2}{*}{3.0} & \multirow[b]{2}{*}{0.2} \\
\hline & $\%$ & 0 & 4.6 & 95.4 & 0 & & \\
\hline \multirow{2}{*}{$\begin{array}{l}\text { Üreticilerin piyasalar hakkında bilgi } \\
\text { yetersizliği } \\
\text { Insufficient knowledge about market }\end{array}$} & $\mathrm{n}$ & 4 & 18 & 43 & 65 & \multirow[b]{2}{*}{2.6} & \multirow[b]{2}{*}{0.6} \\
\hline & $\%$ & 6.2 & 27.7 & 66.2 & 100.0 & & \\
\hline \multirow{2}{*}{$\begin{array}{l}\text { İşleme tesislerinin nitelik olarak } \\
\text { yetersiz olması } \\
\text { Inadequate quality of processing } \\
\text { facilities }\end{array}$} & $\mathrm{n}$ & 22 & 6 & 37 & 65 & \multirow[b]{2}{*}{2.2} & \multirow[b]{2}{*}{0.9} \\
\hline & $\%$ & 33.8 & 9.2 & 56.9 & 100.0 & & \\
\hline \multirow{2}{*}{$\begin{array}{l}\text { İşleme tesislerinin sayılarının azlığı } \\
\text { The low number of processing plants }\end{array}$} & $\mathrm{n}$ & 27 & 4 & 34 & 65 & \multirow{2}{*}{2.1} & \multirow{2}{*}{1.0} \\
\hline & $\%$ & 41.5 & 6.2 & 52.3 & 100.0 & & \\
\hline \multirow{2}{*}{$\begin{array}{l}\text { Sözleşmeli üretim yapılmaması } \\
\text { Lack of contracted production }\end{array}$} & $\mathrm{n}$ & 13 & 44 & 8 & 65 & \multirow{2}{*}{1.9} & \multirow{2}{*}{0.6} \\
\hline & $\%$ & 20.0 & 67.7 & 12.3 & 100.0 & & \\
\hline \multirow{2}{*}{$\begin{array}{l}\text { Alıcılara güven duyulmaması } \\
\text { Lack of confidence toward traders }\end{array}$} & $\mathrm{n}$ & 15 & 40 & 10 & 65 & \multirow{2}{*}{1.9} & \multirow{2}{*}{0.6} \\
\hline & $\%$ & 23.1 & 61.5 & 15.4 & 100.0 & & \\
\hline \multirow{2}{*}{$\begin{array}{l}\text { Dereceleme olanaklarının yetersizliği } \\
\text { Inadequate grading facilities }\end{array}$} & $\mathrm{n}$ & 57 & 8 & 0 & 65 & \multirow{2}{*}{1.1} & \multirow{2}{*}{0.3} \\
\hline & $\%$ & 87.7 & 12.3 & 0 & 100.0 & & \\
\hline \multirow{2}{*}{$\begin{array}{l}\text { Paketleme olanaklarının yetersizliği } \\
\text { Inadequate packaging facilities }\end{array}$} & $n$ & 58 & 6 & 1 & 65 & \multirow{2}{*}{1.1} & \multirow{2}{*}{0.4} \\
\hline & $\%$ & 89.2 & 9.2 & 1.5 & 100.0 & & \\
\hline \multirow{2}{*}{$\begin{array}{l}\text { Pazara taşımada aksaklıklar } \\
\text { Problems in transportation }\end{array}$} & $n$ & 59 & 4 & 2 & 65 & \multirow{2}{*}{1.1} & \multirow{2}{*}{0.4} \\
\hline & $\%$ & 90.8 & 6.2 & 3.1 & 100.0 & & \\
\hline
\end{tabular}

\section{Sonuçlar}

Türkiye'de 2000-2016 yılları arasında bağ alanları 5.4 milyon dekardan 4.7 milyon dekara gerilemiştir. Bu dönemde üzüm veriminde meydana gelen artış sonucu üretim 3.6 milyon tondan 4.4 milyon tona yükselmiştir. Bağcılık yapılan illerden bir tanesi de Gaziantep'tir. Gaziantep ilinin, Türkiye'nin toplam üzüm üretimi içerisindeki payı \%3.7'dir.

Gaziantep, üretim ve dış satım açısından oldukça önemli bir potansiyel olmasına rağmen, bu ilde bağ dikim alanları ve üzüm üretimi gerilemektedir. $\mathrm{Bu}$ nedenle bölgede üzüm pazarlamasında yaşanan sorunların belirlenerek çözüm önerilerinin sunulması oldukça önemlidir. Yapılan çalışma ile Gaziantep ilinde bağcılık üzüm işletmelerinin üretici düzeyinde üzüm pazarlama yapısı ortaya konulmuş ve üreticilerin üzüm pazarlamasında karşılaştıkları sorunlar belirlenmiştir. Çalışma kapsamında, üzüm pazarlamasında yaşanan sorunların çözümüne yönelik öneriler maddeler halinde sunulmuştur;

1. Araştırma alanında üzüm ve ürünlerinin işlenmesi ve pazarlanmasında faaliyet gösteren üretici örgütleri veya kooperatifleri bulunmamaktadır. Oysa ki, üreticiler büyük oranda (\%89.2) üzüm ve 
ürünlerinin pazarlaması konusunda faaliyet gösterecek bir kooperatifin daha faydalı olacağını düşünmektedir. Böyle bir kooperatiften en büyük beklentiler ise pazarlama da alternatif haline gelmesi, ödemelerin zamanında yapılması, markalaşmayla ilgili öncülük sağlaması ve daha iyi fiyat olanağı sağlamasıdır. Başka bir ifadeyle üreticiler daha yüksek fiyattan ürünlerini satabilecekleri bir alıcıya ihtiyaç duymakta ve ürünlerinin markalaşabileceğini düşünmektedir. Araştırma alanında kurulacak üretici örgütleri veya pazarlama kooperatifleri ürünlerin standartlara uygun şekilde paketlenmesine, muhafazasına ve taşınmasına önemli katkılarda bulunacak, pazarlama hizmetlerinin gerçekleştirilmesinde maliyeti azaltacak, ürünlerin düzenli olarak piyasaya sunulmasını ve satışını sağlayacaktır.

2. Üreticiler, araştırma alanındaki işleme tesislerinin sayısının oldukça az olduğunu ifade etmektedir. Üzümün çabuk bozulabilir bir ürün olmasından dolayı üreticiler ürünlerini hasadın hemen sonrasında, bazı zamanlarda oldukça düşük fiyatla satmak zorunda kalmaktadır. Araştırma alanında işleme tesislerinin olması sofralık üzümün düşük fiyatla satılması zorunluluğu ortadan kaldırarak, daha yüksek katma değerli ürünlere işlenmesine olanak sağlayacaktır. Bu durum standart kalitede ürün elde edilmesine ve markalaşmaya da katkı sağlayacaktır. Aynı zamanda üretici gelirlerinde artış ve bölge ekonomisinin kalkınmasında önemli rol oynayacaktır.
3. Markalaşmaya önem verilmelidir. Bölgede girişimciler ortak bir ticari marka oluşturulması ve yönetilmesi konularında bilinçlendirilmeli, özendirilmeli ve desteklenmelidir. Bu şekilde ortak bir markanın oluşturulması hem ürün kalitesinin artırılmasına hem de pazarlama hizmetlerinin daha etkin şekilde yerine getirilmesine katkı sağlayacaktır.

4. Araştırma alanında az sayıda üretici hasat ettiği ürüne dereceleme yapmaktadır. Bu durum, standart ürün elde edilmesini, ürünün markalaşmasını, pazar talebini ve fiyatını olumsuz olarak etkileyen unsurlardır. Üreticiler ürünün derecelenmesinin önemi ile ilgili bilgilendirilmelidir.

5. Bölgede, sadece bağcılık konusunda araştırmaların yapıldığı araştırma enstitüsü veya üretim istasyonu niteliğinde bir kurum bulunmamaktadır. Gaziantep ilinde bağcılık üretim teknikleri ve elde edilen ürünlerin özellikleriyle ilgili az sayıda bilimsel çalışma mevcuttur. Bu kapsamda araştırma ve geliştirme faaliyetleri gerçekleştirecek araştırma birimleri kurulmalı ve bunlar arasında koordinasyon sağlanmalıdır.

6. Üreticilerin piyasalar hakkındaki bilgi yetersizliği, pazarın saydamlığı açısından eksiklikler olduğunu göstermektedir. Piyasadaki ürün arz ve talebi konusunda bilginin toplanması ve yayılmasında sorunlar önemli şekilde hissedilmektedir. Yurtiçi ve yurtdışı pazar bilgilerini toplayıp, tüm sektör paydaşlarına yayacak etkin bir haberleşme ve bilgi ağı oluşturulmalıdır 


\section{7. Üreticilerin üretim tekniği} konusundaki bilgi yetersizliği, elde edilen üründe miktar ve kalite kayıplarına sebep olmaktadır. Bakım işlemleriyle ilgili geliştirilmesi gereken hususlar ayrıntılı olarak belirlenmeli, sorunların giderilmesi için gerekli çalışmalar, öncelikliler de dikkate alınarak belirli plan ve programlar çerçevesinde yapılmalıdır.

\section{Kaynaklar}

Arslan, S. 2016. Üzüm-2015. Tarımsal Ekonomi ve Politika Geliştirme Enstitüsü. Ankara

Aujla, K. M., Shah, N. A., Ishaq, M. 2011. PostHarvest Losses and Marketing of Grapes in Pakistan. Sarhad J. Agric. 27 (3): 485-490.

Cebeci, E., Akın, A., 2014. Mersin İli Üzüm İhracatının Türkiye Ekonomisi İçindeki Yeri ve Öneminin Değerlendirilmesi. Çanakkale Onsekiz Mart Üniversitesi Ziraat Fakültesi Dergisi, 2(2): 119-129.

Çakır, A., Karakaya, E; Uçar, H.K. 2015. Mardin ili Savur İlçesi Bağ İşletmelerinin Mevcut Durumu ve Potansiyeli. Iğdır Üniversitesi Fen Bilimleri Enstitüsü Dergisi. 5(1): 9-19.

Çalkan, Ö.S., Güler, A. 2007. Üzümün Değerlendirme Şekilleri. Tarım Türk Dergisi, 6:7-8.

Çelik, H., Kunter, B., Söylemezoğlu, G., Ergül, A., Çelik, H., Karataş, H., Özdemir, G., Atak, A. 2010. Bağcılığın Geliştirilmesi Yöntemleri ve Üretim Hedefleri. Ziraat Mühendisliği VII. Teknik Kongresi. 11-15 Ocak, Bildiriler Kitabı-1, 493-513s. Ankara.

Çoban, H., Kara, S., Kısmalı, İ. 2001. Alaşehir ve Buldan İlçelerinde Mevcut Bağ İşletmelerinin Yapısının Belirlenmesi Üzerinde Bir Araştırma. Ege Üniversitesi Ziraat Fakültesi Dergisi. 38(1): 17-24.

Geyikçi, U.B. 2013. Manisa İlinin Üzüm Üretimindeki Durumunun Tespitine Yönelik Alan Araştırması ve GZFT Analizi. Celal Bayar Üniversitesi Sosyal Bilimler Dergisi, 11(3): 468-487.

Gooch, M., Laplain, D., Stiefelmeyer, K., Marenick, N, Felfel, A., Ingratta, F., Martin, L. 2009. Consumer Market Research Strategic Study for Fresh Grapes and Fresh
\& Processed Apples \& Tender Fruit \& Orchard Fruit \& Vineyard Quality Assessment throughout the Value Chain. Vineland Research and Innovation Centre. http://vcm-international.com/wpcontent/uploads/2013/10/Vineland-Final111009.pdf. Erişim tarihi: 24.11.2017.

Gözener, B., Kaya, Y., Sayılı, M. 2014. Erzincan İli Üzümlü İlçesinde Cimin Üzümü Üretimi ve Pazarlama Durumu. Gaziosmanpaşa Bilimsel Araştırma Dergisi. 9: 74-80.

Huang, J., Wu, Y., Zhi, H., Rozelle, S., 2008. Small Holder Incomes, Food Safety and Producing, and Marketing China's Fruit. Applied Economic Perspectives and Policy. 30 (3): 469-479.

Kalimang`asi, N., Majula, R. Kalimang’asi, N. 2014. The Economic Analysis of the Smallholders Grape Production and Marketing in Dodoma Municipal: A case study of Hombolo Ward. International Journal of Scientific and Research Publications. 4 (10): 2250-3153.

Karakaş, S. 2015. Bağcılık Dersi Notları - Bağcılıkta Hasat ve Sonrası İşlemler. https://bagcilik.files.wordpress.com/2015/ 05/4-modc3bcl.pdf. Erişim tarihi: 30.12.2016.

Kiracı, M.A., Özer, C. 2007. Trakya Yöresinde Bağcılık İşletmelerinin Üretim ve Pazarlama Yapısı, Sorunları ve Çözüm Önerileri. V. Ulusal Bahçe Bitkileri Kongresi, 5-7 Eylül, 2: 440-446s. Erzurum.

Semerci, A., Kızıltuğ, T., Çelik, A.D., Kiracı, M.A. 2015. Türkiye Bağcılığının Genel Durumu. Mustafa Kemal Üniversitesi Ziraat Fakültesi Dergisi. 20(2): 42-51.

Tasevska, G. M., 2012 Efficiency Analysis of Commercial Grape-Producing Family Farms in the Republic of Macedonia. Doktora Tezi. Swedish University of Agricultural Sciences. Uppsala.

Tüfekçi, Ö.K., ve Tüfekçi, N. 2006. Buldan ve Çevresindeki Üzüm Üreticisinin Pazarlama Sorunları ve Çözüm Önerileri. Buldan Sempozyumu, 23-24 Kasım, Pamukkale Üniversitesi Buldan Meslek Yüksekokulu, Denizli.

TÜiK, 2017. Bitkisel Üretim İstatistikleri Veritabanı. Türkiye İstatistik Kurumu, www.tuik.gov.tr. Erişim tarihi: 15.02.2017. 